\title{
Laparoscopic resection of liver tumors
}

\author{
Ankush Golhar, Vinayak Nikam, Prashantha Rao, Ravi Mohanka \\ Department of Hepato-Biliary Surgery and Liver Transplant, Global Hospital, Mumbai 400012, India.
}

Correspondence to: Dr. Ravi Mohanka, Chief Surgeon and Head of Department, Department of Hepato-Biliary Surgery and Liver Transplantation, Global Hospital, Mumbai 400012, India. E-mail: ravimohanka@gmail.com

How to cite this article: Golhar A, Nikam V, Rao P, Mohanka R. Laparoscopic resection of liver tumors. Mini-invasive Surg 2019;3:9. http://dx.doi.org/10.20517/2574-1225.2018.58

Received: 21 Aug 2018 First Decision: 23 Oct 2018 Revised: 23 Feb 2019 Accepted: 4 Mar 2019 Published: 17 Apr 2019

Science Editor: Fernando Andrés Alvarez Copy Editor: Cai-Hong Wang Production Editor: Huan-Liang Wu

\begin{abstract}
Laparoscopic liver resection is technically challenging compared to open liver surgery and has a steep learning curve. Tumors located in the posterior sector, centrally, in proximity of major vascular pedicles or in a background of liver cirrhosis are surgically more complex with a higher risk of blood loss. There is emerging consensus about indications for laparoscopic liver resection. While laparoscopic approach is considered standard for left lateral sectionectomy and minor laparoscopic liver resections in antero-lateral segments, with increasing experience, major resections, parenchyma sparing resections and even donor hepatectomies are being performed laparoscopically with good outcomes. Laparoscopic liver surgery is feasible and safe for well selected patients by well-trained surgeons with short-term advantages and non-inferior long-term oncologic outcomes.
\end{abstract}

Keywords: Laparoscopic liver surgery, liver tumors, hepatocellular cancer

\section{INTRODUCTION}

Laparoscopic liver resection (LLR) is performed for benign as well as malignant liver tumors. Its adoption has been relatively slow, although the benefits of LLR compared to open liver resection (OLR) are similar to other laparoscopic surgeries, such as lesser peri-operative blood loss, shorter hospital stay and fewer post-operative complications ${ }^{[1]}$. The first international consensus conference to define its role was held at Louisville (USA) in 2008 where it was suggested that LLR was best suited for solitary lesions smaller than $5 \mathrm{~cm}$ in diameter, located in the anterior segments of liver, away from the hepatic hilum or the vena cava so that an adequate resection margins could be obtained ${ }^{[1]}$. The conference also recommended creation of an international registry for ongoing assessment of outcomes with its increasing adoption by surgeons ${ }^{[1]}$. More

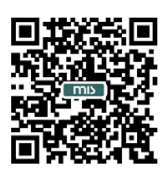


Table 1. Salient features of recommendations by the First European Guidelines Meeting on Laparoscopic Liver Surgery

\begin{tabular}{|c|c|}
\hline Indications for LLR & Comments \\
\hline \multirow[t]{3}{*}{ 1. CRLM } & $\begin{array}{l}\text { LLR is a valid alternative to OLR in experienced hands for CRLM. As compared to OLR, LLR has better short term } \\
\text { outcomes and equivalent oncological and long term survival outcomes for CRLM }\end{array}$ \\
\hline & $\begin{array}{l}\text { When feasible parenchyma sparing approach should be adopted during LLR, but it should not lead to alteration in the } \\
\text { present indications for liver resection in CRLM }\end{array}$ \\
\hline & $\begin{array}{l}\text { Combined liver and colon resection should be adopted in highly selected cases only for CRLM. Timing of colon and } \\
\text { liver resection in synchronous disease is similar to OLR }\end{array}$ \\
\hline \multirow{2}{*}{$\begin{array}{l}\text { 2. Benign tumors and } \\
\text { non-colorectal liver } \\
\text { metastases }\end{array}$} & $\begin{array}{l}\text { Benign tumors and tumors with malignant potential are suitable for LLR with satisfactory short term post-operative } \\
\text { outcomes. LLR should not alter the indications for liver resection in such tumors }\end{array}$ \\
\hline & LLR is an acceptable approach for metastases from neuroendocrine and non-colorectal liver metastases \\
\hline \multirow[t]{6}{*}{ 3. HCC } & $\begin{array}{l}\text { In selected patients LLR offers better short term post-operative outcomes such as decreased morbidity and hospital } \\
\text { stay without compromising oncological outcomes }\end{array}$ \\
\hline & $\begin{array}{l}\text { Indications LLR are similar to those for OLR in case of HCC. Laparoscopic resection for tumors located in postero- } \\
\text { superior (Segment } 1,4 a, 7,8 \text { ) segments should be done only at experienced centers }\end{array}$ \\
\hline & In experienced hands major LLR is appropriate option to OLR in highly selected patients \\
\hline & $\begin{array}{l}\text { Outcomes of left and right laparoscopic hepatectomy should be reported separately as they vary significantly. } \\
\text { Laparoscopic right hepatectomy should be further developed in major liver centers }\end{array}$ \\
\hline & $\begin{array}{l}\text { In patients with HCC, as for other indications, selective use of intermittent Pringle's maneuver may help decrease the } \\
\text { blood loss without detrimental effect on liver function }\end{array}$ \\
\hline & $\begin{array}{l}\text { In patients with cirrhosis, LLR may be associated with less risk of post-operative ascites and liver decompensation. } \\
\text { Minor LLR for single and peripheral HCC in selected Child B patients warrants cautious approach and further } \\
\text { evaluation is needed }\end{array}$ \\
\hline \multirow[t]{3}{*}{ 4. LDH } & LDH requires expertise in both liver transplantation and laparoscopic liver surgery \\
\hline & $\begin{array}{l}\text { Laparoscopic left lateral sectionectomy for pediatric liver transplantation offers reduction in blood loss, morbidity and } \\
\text { hospital stay and should be considered equivalent to OLR }\end{array}$ \\
\hline & $\begin{array}{l}\text { Adult liver transplantation: LDH is not yet standardized in terms of donor selection and surgical technique. Its safety } \\
\text { and postoperative outcomes needs to be evaluated in experienced center further }\end{array}$ \\
\hline
\end{tabular}

CRLM: colorectal liver metastases; LLR: laparoscopic liver resection; OLR: open liver resection; LDH: laparoscopic donor hepatectomy; HCC: hepatocellular carcinoma

recently, the second international consensus conference held at Morioka (Japan) in 2014, recommended that minor LLR to be considered as a standard practice and major LLR as an innovative procedure, under exploration $^{[2]}$. The first European Guidelines Meeting on Laparoscopic Liver Surgery at Southampton in February 2017 summarized available evidence for LLR for different liver tumors, types of resections and clinical situations. Few salient points relevant to this article have been summarized in Table $1^{[3]}$.

\section{TECHNICAL CHALLENGES IN LAPAROSCOPIC LIVER SURGERY}

Detailed understandings of the hilar and segmental anatomy of the liver and adequate experience with OLR are pre-requisites for performing $\operatorname{LLR}^{[3]}$. The laparoscopic view is caudo-cranial for hilar dissection as well as the parenchymal transection compared to the antero-posterior view in $\operatorname{OLR}^{[4]}$. Liver being a heavy and deep seated organ, especially its right lobe, may be difficult to maneuver. Liver tumors most often develop in a background of liver cirrhosis with stiff parenchymal tissue and collaterals due to portal hypertension, which makes the operation more difficult and increases the risk of bleeding ${ }^{[4]}$. Tumors located in postero-superior or central segments, large tumors and intra-abdominal adhesions secondary to previous hepato-pancreato-biliary (HPB) surgeries can further make LLR more difficult ${ }^{[4]}$. The learning curve for LLR is steep requiring about 45 to 60 cases before improvements in operative time, blood loss and post-operative complications are apparent ${ }^{[5,6]}$.

\section{TECHNIQUE OF LAPAROSCOPIC LIVER SURGERY}

LLR may be performed purely laparoscopic, hand-assisted, using the hybrid technique or by robotic assisted approaches ${ }^{[4,5,7,8]}$. Port placement varies by tumor location, type of resection planned, patient positioning and surgeon's preference ${ }^{[7]}$. Generally an umbilical port is used for the camera and directed 
towards the tumor and about 4 to 5 working ports for graspers, suction, ultrasonic or sealing energy devices, cavitron ultrasonic surgical aspirator (CUSA) and others are placed on either side of the camera port at a reasonable distance ${ }^{[7]}$. In hand-assisted technique, in addition to the regular ports a hand-port is used to help mobilize the liver and retract both cut surfaces during the transection ${ }^{[7]}$. The hybrid technique involves mobilization laparoscopically followed by parenchymal transection and specimen extraction through a small open incision and may combine the benefits of both techniques ${ }^{[8]}$. Robot assisted LLR offers the advantage of a 3 dimensional vision and dexterity of robotic arms whereas parenchymal transection is performed laparoscopically with access to better retractors and CUSA. Robot assisted LLR may be more suited for postero-superior segment tumors ${ }^{[4]}$.

LLR involves the following steps, not necessarily in the same order:

- Hilar dissection followed by inflow control is obtained fairly early during the LLR. Inflow control may be obtained by intra-fascial or Glissonian approach depending on tumor factors and surgeon's preferences, as both are safe ${ }^{[3,6,9]}$. Biliary anatomy can be deciphered using fluorescence, conventional contrast or combined cholangiography ${ }^{[10]}$. Either intrabiliary injection of $0.025-0.5 \mathrm{mg} / \mathrm{mL}$ indocyanine green (ICG) or intravenous injection of $2.5 \mathrm{mg}$ ICG fifteen minutes before fluoroscopy can be used to identify biliary anatomy and plan division of the bile ducts ${ }^{[10]}$.

- Approach for laparoscopic right hepatectomy may be by anterior approach or conventional approach after mobilisation of liver ${ }^{[3,11,12]}$.

- The transection plane is identified for left or right hepatic resection by unilateral clamping vascular inflow of same side at the hilum or by fluorescence imaging with $\mathrm{ICG}^{[10]}$. After clamping the portal pedicle supplying segment to be removed, boundaries of hepatic segments can be visualized following injection of $0.25-2.5 \mathrm{mg} / \mathrm{mL}$ ICG into the portal veins or by intravenous injection of $2.5 \mathrm{mg} \mathrm{ICG}{ }^{[10]}$. For segmental or non-anatomical resection, the transection plane may be identified using the Glissonian approach or intra-operative Doppler Ultrasonography ${ }^{[3,13]}$.

- Cholecystectomy: some surgeons although disconnect the cystic artery and duct, retain the gall bladder for retraction until later in the case.

- Pringle's maneuver, the practice is variable with few centers not using it at all and others using it in all cases $^{[3,1]}$. Parenchymal transection is the most challenging part of the surgery with large variations in technique, instruments, equipment used between different surgeons also depending on the tumor size, location and nature of background liver ${ }^{[3,14]}$. Various transection techniques have been described including the use of the modern dissectors/ aspirators [laparoscopic CUSA, WaterJet (Helix Hydro-Jet Erbe Elektromedizin GmbH, Tuebingen, Germany), etc.], sealing devices [Harmonic scalpel (Ethicon Endo Surgery INC - Johnson \& Johnson Medical SPA, Somerville, NJ), Ligasure (Valleylab Inc., Boulder, Colorado, USA), bipolar sealing devices, etc.], and vascular staplers ${ }^{[3,14]}$. Superficial transection can be performed with any energy device, but deeper transection should be performed with an appropriate device to identify deep vascular structures ${ }^{[3]}$. While large vessels should be secured with vascular staplers or Hem-o-lok clips (Weck Closure Systems, Research Triangle Park, Durham, NC, USA Manufacturer), smaller vessels can be divided using metal or Hem-o-lok clips or sealed with an energy device ${ }^{[3,14]}$. Staplers for parenchymal transection should be used with caution because it lacks precision and identification of the underlying structures ${ }^{[3]}$. Argon Plasma Coagulator (APC) should be used for haemostasis with extreme caution due to the potential risk of gas embolism ${ }^{[3]}$. More recently, a novel technique has been described, called "superficial pre-coagulation, sealing and transection method", which utilizes a soft coagulation system to create a $5 \mathrm{~mm}$ zone of pre-coagulation causing shrinkage and blockage of micro-vessels and bile ducts smaller than $1 \mathrm{~mm}$ without causing sparks and tissue desiccation ${ }^{[15]}$. This is followed by liver parenchymal dissection using CUSA in a bloodless plane created by pre-coagulation ${ }^{[15]}$. Use of the laparoscopic hanging maneuver is also reported by few surgeons ${ }^{[3,16]}$. Intra-operative Doppler Ultrasonography (IOUS) is used for confirming adequate tumor margin from the cut surface ${ }^{[11]}$.

- The specimen may be extracted using an appropriate retrieval bag generally through a midline or pfannenstiel incision. 


\section{TECHNICALLY COMPLEX SITUATIONS}

For centrally located or deep tumors, visual guidance and tactile feedback are limited, and IOUS may be essential for tumor localization, assessment for satellite nodules, planning the resection plane and determining spatial relationship of the tumor with major blood vessels ${ }^{[13]}$. Sub-capsular tumors can be identified by intra-operative fluorescence imaging following preoperative intravenous injection of ICG (0.5 mg per kg body weight) usually given within two weeks of surgery ${ }^{[10]}$. "Diamond technique" has been described for centrally located parenchymal sparing liver resection ${ }^{[17]}$.

Anatomic liver resection for tumors located in postero-superior (segment 7, segment 8) segments and segment $4 \mathrm{a}$ are technically difficult because of difficulty of access and are associated with more blood loss, risk of conversion to open surgery or change to hemi-hepatectomy ${ }^{[18-21]}$. Strategies such as use of a spacer, left lateral position, intercostal ports, hand-assisted, robot-assisted or other approaches have demonstrated reduced blood loss and need for conversion in such tumors ${ }^{[18-21]}$.

Only few cases of isolated laparoscopic caudate lobe resection are reported as it is technically challenging ${ }^{[2,23]}$. Laparoscopy provides good vision of the caudate lobe between the hilar plate and the vena cava from the right side. Division of the gastro-hepatic ligament facilitates visualization and resection from the left $\operatorname{side}^{[22,23]}$. LLR is safe and non-inferior to OLR in the cirrhotic liver too, with lesser blood loss and shorter hospital stay reported in few studies ${ }^{[24]}$.

\section{LLR DIFFICULTY SCORING SYSTEMS AND SELECTION CRITERIA}

The degree of difficulty of LLR depends upon multiple factors ${ }^{[25]}$. A retrospective analysis has found a good agreement between the difficulty level assessed by the surgeon and a difficulty index based on tumor location, extent of liver resection, tumor size, proximity to major vessels, and liver function ${ }^{[25]}$. Although such scoring systems need further refinement and prospective validation, they can be helpful in assessment of trainee surgeon's skills, guide their training, better estimate risks of the procedure ${ }^{[25]}$. Appropriate patient selection, practicing and honing LLR skills is paramount for success ${ }^{[25]}$. Most laparoscopic liver surgeons would accept tumor size of $<5 \mathrm{~cm}$, fewer than three lesions without macroscopic vascular invasion or the need for biliary reconstruction as criteria for $\operatorname{LLR}^{[2,26]}$.

\section{RESULTS OF LAPAROSCOPIC VERSUS OPEN HEPATECTOMY}

\section{Short term outcomes}

Comparison of LLR and OLR

LLR has been found to be significantly better compared to OLR for minor hepatectomies for short-term outcomes such as the operation time, blood loss, and post-operative hospital stay ${ }^{[27]}$. Although there are numerous case-reports and retrospective series of LLR, few well-designed randomized controlled trials (RCTs) and meta-analyses are currently available ${ }^{[27-35]}$. Meta-analyses show that LLR has clinical benefits over OLR with significant reduction in blood loss, blood transfusion, complications and hospital stay with comparable operative time and resection margin positivity. However potential biases due to low statistical power of many studies included in the meta-analyses cannot be undermined ${ }^{[28-35]}$. The results of these studies are summarized in Table 2.

\section{Long term outcomes}

Hepatocellular carcinoma

Current evidence suggests that local tumor recurrence, disease free survival and overall survival are similar between laparoscopic and open resections ${ }^{[39-42]}$. The results of these studies are summarized in Table 3. Although meta-analyses indicate that LLR for hepatocellular carcinoma (HCC) is comparable to OLR in oncological and survival outcomes, they lacked RCTs ${ }^{[36-39]}$. 
Table 2. Previous studies comparing laparoscopic and open liver resection

\begin{tabular}{|c|c|c|c|c|c|c|c|}
\hline Author & Type & Blood loss & Transfusion & $\begin{array}{c}\text { Operative } \\
\text { time }\end{array}$ & $\begin{array}{c}\text { Hospital } \\
\text { stay }\end{array}$ & Complications & $\begin{array}{c}\text { Resection } \\
\text { margin }\end{array}$ \\
\hline $\begin{array}{l}\text { Simillis et al. }{ }^{[28]} \\
(2007)\end{array}$ & $\begin{array}{l}\text { Meta-analysis } \\
8 \text { studies }\end{array}$ & LLR $<$ OLR & $\begin{array}{l}\text { No significant } \\
\text { difference }\end{array}$ & $\begin{array}{l}\text { No significant } \\
\text { difference }\end{array}$ & LLR $<$ OLR & $\begin{array}{l}\text { No significant } \\
\text { difference }\end{array}$ & $\begin{array}{l}\text { No significant } \\
\text { difference }\end{array}$ \\
\hline $\begin{array}{l}\text { Zhou et al. }{ }^{[29]} \\
\text { (2011) }\end{array}$ & $\begin{array}{l}\text { Meta-analysis } \\
21 \text { studies }\end{array}$ & $\mathrm{LLR}<\mathrm{OLR}$ & $\mathrm{LLR}<\mathrm{OLR}$ & $\begin{array}{l}\text { No significant } \\
\text { difference }\end{array}$ & $\mathrm{LLR}<\mathrm{OLR}$ & LLR $<$ OLR & $\begin{array}{l}\text { No significant } \\
\text { difference }\end{array}$ \\
\hline $\begin{array}{l}\text { Rao et al. }{ }^{[30]} \\
(2012)\end{array}$ & $\begin{array}{l}\text { Systematic review } \\
10 \text { studies }\end{array}$ & $\mathrm{LLR}<\mathrm{OLR}$ & $L L R<O L R$ & $\begin{array}{l}\text { No significant } \\
\text { difference }\end{array}$ & $\mathrm{LLR}<\mathrm{OLR}$ & LLR $<$ OLR & $\begin{array}{l}\text { No significant } \\
\text { difference }\end{array}$ \\
\hline $\begin{array}{l}\text { Fancellu et } a l^{[31]} \\
\text { (2011) }\end{array}$ & $\begin{array}{l}\text { Meta-analysis } \\
9 \text { studies }\end{array}$ & $\mathrm{LLR}<\mathrm{OLR}$ & $L L R<O L R$ & $\begin{array}{l}\text { No significant } \\
\text { difference }\end{array}$ & $\mathrm{LLR}<\mathrm{OLR}$ & $L L R<O L R$ & $\begin{array}{l}\text { No significant } \\
\text { difference }\end{array}$ \\
\hline $\begin{array}{l}\text { Li et al. } \\
(2012)\end{array}$ & $\begin{array}{l}\text { Meta-analysis } \\
10 \text { studies }\end{array}$ & $\mathrm{LLR}<\mathrm{OLR}$ & $\mathrm{LLR}<\mathrm{OLR}$ & $\begin{array}{l}\text { No significant } \\
\text { difference }\end{array}$ & $\mathrm{LLR}<\mathrm{OLR}$ & LLR $<$ OLR & $\begin{array}{l}\text { No significant } \\
\text { difference }\end{array}$ \\
\hline $\begin{array}{l}\text { Xiong et al. }{ }^{[33]} \\
(2012)\end{array}$ & $\begin{array}{l}\text { Meta-analysis } \\
16 \text { studies }\end{array}$ & $\mathrm{LLR}<\mathrm{OLR}$ & $\mathrm{LLR}<\mathrm{OLR}$ & $\begin{array}{l}\text { No significant } \\
\text { difference }\end{array}$ & $\mathrm{LLR}<\mathrm{OLR}$ & $\mathrm{LLR}<\mathrm{OLR}$ & $\begin{array}{l}\text { No significant } \\
\text { difference }\end{array}$ \\
\hline $\begin{array}{l}\text { Yin et al. }{ }^{[34]} \\
(2013)\end{array}$ & $\begin{array}{l}\text { Meta-analysis } \\
15 \text { studies }\end{array}$ & $\mathrm{LLR}<\mathrm{OLR}$ & $\mathrm{LLR}<\mathrm{OLR}$ & $\begin{array}{l}\text { No significant } \\
\text { difference }\end{array}$ & $\mathrm{LLR}<\mathrm{OLR}$ & $\mathrm{LLR}<\mathrm{OLR}$ & $\begin{array}{l}\text { No significant } \\
\text { difference }\end{array}$ \\
\hline $\begin{array}{l}\text { Fretland et } a l^{[35]} \\
\text { (2018) }\end{array}$ & $\mathrm{RCT}$ & $\begin{array}{l}\text { No significant } \\
\text { difference }\end{array}$ & $\begin{array}{l}\text { No significant } \\
\text { difference }\end{array}$ & $\begin{array}{l}\text { No significant } \\
\text { difference }\end{array}$ & $\mathrm{LLR}<\mathrm{OLR}$ & $\mathrm{LLR}<\mathrm{OLR}$ & $\begin{array}{l}\text { No significant } \\
\text { difference }\end{array}$ \\
\hline
\end{tabular}

LLR: laparoscopic liver resection; OLR: open liver resection; RCT: randomized controlled trials

\section{Colorectal liver metastases}

Recently published meta-analysis on LLR for colorectal liver metastases (CRLM) concluded that LLR is a beneficial alternative to OLR in selected patients and does not compromise oncological outcomes including surgical margins, tumor recurrence, disease-free survival or 5-year overall survival, with even a possibility of better 3-year overall survival ${ }^{[40]}$. Even though this meta-analysis used propensity matching for compensating for selection bias, differences in proportions of major and minor resections and studies with low statistical power might be a potential source of bias ${ }^{[40]}$. In a recently completed randomized control trial (OSLO-COMET trial) of 280 patients with CRLM, randomized either to laparoscopic $(n=133)$ or open $(n=147)$ liver resection; blood loss, operative time and resection margins were similar in both groups ${ }^{[38]}$ while the post-operative hospital stay was shorter with laparoscopic surgery ( $53 \mathrm{~h} \mathrm{vs.} 96 \mathrm{~h}$ ), complications were significantly less (19\% vs. 31\%), costs were similar at four months while patients in the laparoscopic group gained 0.011 quality adjusted life years ${ }^{[35]}$.

\section{ADVANCES IN LLR}

The scope for LLR is increasing with improvements in LLR skills, availability of surgical gadgets and use of the robotic platform ${ }^{[41]}$. Robotic assistance is promising to aid difficult LLRs such as posterosuperior resections, non-anatomical resections along angulated or curvilinear resection planes, those requiring complex vascular and biliary reconstructions, but these need further refinement in skills and prospective validation ${ }^{[41]}$. Even single incision laparoscopic liver resection has been reported in very suitable tumors ${ }^{[42-44]}$. Few surgeons have reported the feasibility and safety of laparoscopic re-resections for malignant liver tumors, with a satisfactory conversion rate of $15 \%$, although with significantly greater blood loss and operative time compared to primary $\operatorname{LLR}^{[45,46]}$. Laparoscopic re-resection of liver tumors may be feasible even after previous OLR, up to two prior LLRs, after previous major hepatectomy, even in cirrhotic livers and postero-superiorly located tumors ${ }^{[47]}$. Recent advances in LLR also include laparoscopic living donor hepatectomy and laparoscopic associating liver partition and portal vein ligation amongst others ${ }^{[48]}$.

\section{SUMMARY}

LLR is becoming widely accepted for the treatment of both benign and malignant liver tumors especially HCC and CRLM. Laparoscopic left lateral sectionectomy and minor laparoscopic liver resection are now 
Table 3. Studies comparing long-term outcomes of laparoscopic and open liver resection for HCC

\begin{tabular}{|c|c|c|c|c|c|c|c|c|}
\hline Study & Type & 1-year survival & $\begin{array}{c}\text { 3-year } \\
\text { survival }\end{array}$ & $\begin{array}{c}\text { 5-year } \\
\text { survival }\end{array}$ & 1-year DFS & 3-year DFS & 5-year DFS & $\begin{array}{c}\text { Overall and } \\
\text { DFS }\end{array}$ \\
\hline $\begin{array}{l}\text { Parks et al } !^{[36]} \\
(2014)\end{array}$ & Meta-analysis & $\begin{array}{l}L-92 \% \\
O-91.3 \%\end{array}$ & $\begin{array}{l}L-77.7 \% \\
O-76.5 \%\end{array}$ & $\begin{array}{l}L-61.9 \% \\
O-56.5 \%\end{array}$ & NA & NA & NA & NA \\
\hline $\begin{array}{l}\text { Kimet al }{ }_{(2014)}^{[37]} \\
\end{array}$ & $\begin{array}{l}\text { Case matched } \\
\text { with PSM }\end{array}$ & $\begin{array}{l}L-100 \% \\
O-96.5 \%\end{array}$ & $\begin{array}{l}L-100 \% \\
O-92.2 \%\end{array}$ & $\begin{array}{l}L-92.2 \% \\
O-87.7 \%\end{array}$ & $\begin{array}{l}L-81.7 \% \\
O-78.6 \%\end{array}$ & $\begin{array}{l}L-61.7 \% \\
O-60.9 \%\end{array}$ & $\begin{array}{l}L-54 \% \\
O-40.1 \%\end{array}$ & NSD \\
\hline $\begin{array}{l}\text { Han et al. }{ }^{[38]} \\
(2015)\end{array}$ & $\begin{array}{l}\text { Case matched } \\
\text { with PSM }\end{array}$ & $\begin{array}{l}L-91.6 \% \\
O-93.1 \%\end{array}$ & $\begin{array}{l}\text { L- } 87.5 \% \\
O-87.8 \%\end{array}$ & $\begin{array}{l}L-76.4 \% \\
O-73.2 \%\end{array}$ & $\begin{array}{l}L-69.7 \% \\
O-74.7 \%\end{array}$ & $\begin{array}{l}L-52 \% \\
O-49.5 \%\end{array}$ & $\begin{array}{l}L-44.2 \% \\
O-41.2 \%\end{array}$ & NSD \\
\hline $\begin{array}{l}\text { Takahara et al. } .^{[39]} \\
\text { (2015) }\end{array}$ & $\begin{array}{l}\text { Case matched } \\
\text { with PSM }\end{array}$ & $\begin{array}{l}L-95.8 \% \\
O-95.8 \%\end{array}$ & $\begin{array}{l}L-86.2 \% \\
O-84 \%\end{array}$ & $\begin{array}{l}L-76.8 \% \\
O-70.9 \%\end{array}$ & $\begin{array}{l}L-83.7 \% \\
O-79.6 \%\end{array}$ & $\begin{array}{l}L-58.3 \% \\
O-50.4 \%\end{array}$ & $\begin{array}{l}L-40.7 \% \\
O-39.3 \%\end{array}$ & NSD \\
\hline
\end{tabular}

HCC: hepatocellular carcinoma; DFS: disease free survival; PSM: propensity score matching; L: laparoscopic liver resection; O: open liver resection; NSD: no significant difference; NA: not available

considered standard approaches. Major laparoscopic hepatectomy has been shown to be feasible and safe at few select experienced centers. Few meta-analyses have shown that LLR is better than OLR with better short-term and cosmetic outcomes. Long-term oncologic and survival outcomes have been found to be similar to open liver resection in case-matched studies. Although LLR has a steep learning curve, indications for it are expanding fast with advances in laparoscopic techniques and skills.

\section{CONCLUSION}

LLR is a safe and effective approach to liver surgery for well selected patients in the hands of well trained surgeons with experience in hepatobilliary and laparoscopic surgery. The current scientific support in its favour is limited to case series, expert consensus recommendations, guidelines, meta-analyses with very few matched controlled studies and a single randomised controlled trial.

The learning curve is still a problem.

Randomized trials and structured training will help benefit more patients with the advancement in this technique.

\section{DECLARATIONS}

\section{Authors' contributions}

Wrote part of the article: Golhar A, Rao P

Wrote part of the article and reviewed: Nikam $\mathrm{V}$

Conceptualized the article, researched and wrote the outline and part of the article: Mohanka $\mathrm{R}$

\section{Availability of data and materials}

Not applicable.

\section{Financial support and sponsorship}

None.

\section{Conflicts of interest}

All authors declared that there are no conflicts of interest.

\section{Ethical approval and consent to participate}

Not applicable.

\section{Consent for publication}

Not applicable. 


\section{Copyright}

(C) The Author(s) 2019.

\section{REFERENCES}

1. Buell JF, Cherqui D, Geller DA, O'Rourke N, Iannitti D, et al. The international position on laparoscopic liver surgery: The Louisville Statement, 2008. Ann Surg 2009;250:825-30.

2. Wakabayashi G, Cherqui D, Geller DA, Buell JF, Kaneko H, et al. Recommendations for laparoscopic liver resection: a report from the second international consensus conference held in Morioka. Ann Surg 2015;261:619-29.

3. Hilal MA, Aldrighetti L, Dagher I, Edwin B, Torisi RI, et al. The Southampton consensus Guidelines for laparoscopic liver surgery. Ann surg 2018;268:11-8.

4. Boggi U, Caniglia F, Vistoli F, Costa F, Pieroni E, et al. Laparoscopic robot-assisted resection of tumors located in posterosuperior liver segments. Updates Surg 2015;67:177-83.

5. Brown KM, Geller DA. What is the Learning Curve for Laparoscopic Major Hepatectomy? J Gastrointest Surg 2016;20:1065-71.

6. Lin CW, Tsai TJ, Cheng TY, Wei HK, Hung CF, et al. The learning curve of laparoscopic liver resection after the Louisville statement 2008: Will it be more effective and smooth? Surg Endosc 2016;30:2895-903.

7. Fong Y, Jarnagin W, Conlon KC, Demattero R, Dougherty E, et al. Hand assisted laparoscopic liver resection: Lessons from initial experience. Archives of Surgery 2000;135:845-9.

8. Koffron AJ, Kung RD, Auffenberg GB, Abecassis MM. Laparoscopic liver surgery for everyone: the hybrid method. Surgery 2007;142:463-8; discussion 468.e1-2.

9. Machado MA, Surjan RC, Basseres T, Schadde E, Costa FP, et al. The laparoscopic Glissonian approach is safe and efficient when compared with standard laparoscopic liver resection: Results of an observational study over 7 years. Surgery 2016;160:643-51.

10. Kudo H, Ishizawa T, Tani K, Harada N, Ichida A, et al. Visualization of subcapsular hepatic malignancy by indocyanine-green fluorescence imaging during laparoscopic hepatectomy. Surg Endosc 2014;28:2504-8.

11. Chen HW, Deng FW, Wang FJ, Li JY, Lai EC, et al. Laparoscopic Right Hepatectomy Via an Anterior Approach for Hepatocellular Carcinoma. JSLS 2018;22:e2017.00084.

12. Soubrane O, Schwarz L, Cauchy F, Perotto LO, Brustia R, et al. A conceptual technique for laparoscopic right hepatectomy based on facts and oncologic principles: the caudal approach. Ann Surg 2015;261:1226-31.

13. Torzilli G, Makuuchi M. Intraoperative ultrasonography in liver cancer. Surg Oncol Clin N Am 2003;12:91-103.

14. Otsuka Y, Kaneko H, Cleary SP, Buell JF, Cai X, et al. What is the best technique in parenchymal transection in laparoscopic liver resection? Comprehensive review for the clinical question on the 2nd International Consensus Conference on Laparoscopic Liver Resection. Journal of Hepato-Biliary-Pancreatic Sciences. 2015;22:363-70.

15. Itano O, Ikoma N, Takei H, Oshima G, Kitagawa Y. The superficial precoagulation, sealing, and transection method: a "bloodless" and "ecofriendly" laparoscopic liver transection technique. Surg Laparosc Endosc Percutan Tech 2015;25:e33-6.

16. Dokmak S, Ben Safta Y, Ftériche FS, Aussilhou B, Belghiti J. Pure laparoscopic right hepatectomy with the hanging maneuver for multiple hepatocellular adenomas. Ann Surg Oncol 2014;21:3800-1.

17. Cipriani F, Shelat VG, Rawashdeh M, Francone E, Aldrighetti L, et al. Laparoscopic parenchymal-sparing resections for nonperipheral liver lesions, the diamond technique: technical aspects, clinical outcomes, and oncologic efficiency. J Am Coll Surg 2015;221:265-72.

18. Kim YK, Han HS, Yoon YS, Cho JY, Lee W. Total anatomical laparoscopic liver resection of segment 4 (S4), extended S4, and subsegments S4a and S4b for hepatocellular carcinoma. J Laparoendosc Adv Surg Tech A 2015;25:375-9.

19. Ikeda T, Toshima T, Harimoto N, Yamashita Y, Ikegami T, et al. Laparoscopic liver resection in the semiprone position for tumors in the anterosuperior and posterior segments, using a novel dual-handling technique and bipolar irrigation system. Surg Endosc 2014;28:2484-92.

20. Lee W, Han HS, Yoon YS, Cho JY, Choi Y, et al. Role of intercostal trocars on laparoscopic liver resection for tumors in segments 7 and 8. J Hepatobiliary Pancreat Sci 2014;21:65-8.

21. Morise Z. Laparoscopic liver resection for posterosuperior tumors using caudal approach and postural changes: a new technical approach. World J Gastroenterol 2016;22:10267-74.

22. Salloum C, Lahat E, Lim C, Doussot A, Osseis M, et al. Laparoscopic isolated resection of caudate lobe (Segment 1): a safe and versatile technique. J Am Coll Surg 2016;222:e61-6.

23. Dulucq JL, Wintringer P, Stabilini C, Mahajna A. Isolated laparoscopic resection of the hepatic caudate lobe: surgical technique and a report of 2 cases. Surgical Laparoscopy Endoscopy \& Percutaneous Techniques 2006;16:32-5.

24. Twaij A, Pucher PH, Sodergren MH, Gall T, Darzi A, et al. Laparoscopic vs open approach to resection of hepatocellular carcinoma in patients with known cirrhosis: systematic review and meta-analysis. World J Gastroenterol 2014;20:8274-81.

25. Ban D, Kudo A, Ito H, Mitsunori Y, Matsumura S, et al. The difficulty of laparoscopic liver resection. Updates Surg 2015;67:123-8.

26. Shelat VG, Cipriani F, Basseres T, Armstrong TH, Takhar AS, et al. Pure laparoscopic liver resection for large malignant tumors: does size matter? Ann Surg Oncol 2015;22:1288-93.

27. Carswell KA, Sagias FG, Murgatroyd B, Rela M, Heaton N, et al. Laparoscopic versus open left lateral segmentectomy. BMC surgery 2009;9:14

28. Simillis C, Constantinides VA, Tekkis PP, Darzi A, Lovegrove R, et al. Laparoscopic versus open hepatic resections for benign and malignant neoplasms - a meta-analysis. Surgery 2007;141:203-11.

29. Zhou YM, Shao WY, Zhao YF, Xu DH, Li B. Meta-analysis of laparoscopic versus open resection for hepatocellular carcinoma. Dig Dis Sci 2011;56:1937-43.

30. Rao A, Rao G, Ahmed I. Laparoscopic or open liver resection? Let systematic review decide it. Am J Surg. 2012;204:222-31. 
31. Fancellu A, Rosman AS, Sanna V, Nigri GR, Zorcolo L, et al. Meta-analysis of trials comparing minimally-invasive and open liver resections for hepatocellular carcinoma. J Surg Res 2011;171:e33-45.

32. Li N, Wu YR, Wu B, Lu MQ. Surgical and oncologic outcomes following laparoscopic versus open liver resection for hepatocellular carcinoma: a meta-analysis. Hepatol Res 2012;42:51-9.

33. Xiong JJ, Altaf K, Javed MA, Huang W, Mukherjee R, et al. Meta-analysis of laparoscopic vs open liver resection for hepatocellular carcinoma. World J Gastroenterol 2012;18:6657-68.

34. Yin Z, Fan X, Ye H, Yin D, Wang J. Short- and long-term outcomes after laparoscopic and open hepatectomy for hepatocellular carcinoma: a global systematic review and meta-analysis. Ann Surg Oncol 2013;20:1203-15.

35. Fretland AA, Dagenborg VJ, Bjørnelv GM, Kazaryan AM, Kristiansen R, et al. Laparoscopic versus open resection for colorectal liver metastases. Annals of surgery. 2018;267:199-207.

36. Parks KR, Kuo YH, Davis JM, O’ Brien B, Hagopian EJ. Laparoscopic versus open liver resection: a meta-analysis of long-term outcome. HPB (Oxford) 2014;16:109-18.

37. Kim H, Suh KS, Lee KW, Yi NJ, Hong G, et al. Long-term outcome of laparoscopic versus open liver resection for hepatocellular carcinoma: a case-controlled study with propensity score matching. Surg Endosc 2014;28:950-60.

38. Han HS, Shehta A, Ahn S, Yoon YS, Cho JY, et al. Laparoscopic versus open liver resection for hepatocellular carcinoma: case-matched study with propensity score matching. J Hepatol 2015;63:643-50.

39. Takahara T, Wakabayashi G, Beppu T, Aihara A, Hasegawa K, et al. Long-term and perioperative outcomes of laparoscopic versus open liver resection for hepatocellular carcinoma with propensity score matching: a multi-institutional Japanese study. J Hepatobiliary Pancreat Sci 2015;22:721-7.

40. Zhang XL, Liu RF, Zhang D, Zhang YS, Wang T. Laparoscopic versus open liver resection for colorectal liver metastases: a systematic review and meta-analysis of studies with propensity score-based analysis. Int J Surg 2017;44:191-203.

41. Tranchart H, Ceribelli C, Ferretti S, Dagher I, Patriti A. Traditional versus robot-assisted full laparoscopic liver resection: a matchedpair comparative study. World J Surg 2014;38:2904-9.

42. Ban D, Kudo A, Irie T, Ochiai T, Aihara A, et al. Advances in reduced port laparoscopic liver resection. Asian J Endosc Surg. 2015;8:11-5.

43. Tan EK, Lee VT, Chang SK, Ganpathi IS, Madhavan K, et al. Laparoendoscopic single-site minor hepatectomy for liver tumors. Surg Endosc 2012;26:2086-91.

44. Shetty GS, You YK, Choi HJ, Na GH, Hong TH, et al. Extending the limitations of liver surgery: outcomes of initial human experience in a high-volume center performing single-port laparoscopic liver resection for hepatocellular carcinoma. Surg Endosc 2012;26:1602-8.

45. Goh BK, Teo JY, Chan CY, Lee SY, Cheow PC, et al. Review of 103 Cases of Laparoscopic Repeat Liver Resection for Recurrent Hepatocellular Carcinoma. J Laparoendosc Adv Surg Tech A 2016;26:876-81.

46. Shelat VG, Serin K, Samim M, Besselink MG, Al Saati H, et al. Outcomes of repeat laparoscopic liver resection compared to the primary resection. World J Surg 2014;38:3175-80.

47. Hu M, Zhao G, Xu D, Liu R. Laparoscopic repeat resection of recurrent hepatocellular carcinoma. World J Surg 2011;35:648-55.

48. Schön MR, Justinger C. Laparoscopic liver resection. Chirurg. 2017;88:469-75. 